VIDEO SURGERY TECHNIQUES

\title{
HOW TO HARVEST RADIAL FOREARM FREE FLAP
}

\section{Parintosa Atmodiwirjo1, Mohamad Rachadian Ramadan1, Sara Ester Triatmoko1, Nadhira Anindita Ralena²}

1. Reconstructive Microsurgery Section, Division of Plastic Surgery, Faculty of Medicine Universitas Indonesia, dr. Cipto Mangunkusumo National Hospital. Jakarta, Indonesia.

2. Faculty of Medicine, Universitas Indonesia. Jakarta, Indonesia

\begin{abstract}
Summary: Radial forearm flap is fasciocutaneous flap from the volar aspect of the forearm that based on the perforator of radial artery. Radial forearm free flap (RFFF) has several advantages and disadvantages. It has unique characteristic of thin and pliable tissue. It may be indicated when a defect requires a thin flap with little bulk of soft tissue or multiple skin islands are needed to be provided. Physical signs and symptoms of poor peripheral digit perfusion or healing contraindicate the harvest of the radial artery pedicle. Preparations for RFFF procedure include history taking, physical examinations and supporting examinations. Several steps of intraoperative preparations should also be conducted.

Keywords: Radial Forearm Free Flap; Microsurgery; Reconstructive Microsurgery, Flaps

Ringkasan: Radial forearm flap adalah flap fasiokutan dari aspek volar lengan bawah yang berdasar pada perforator arteri radialis. Radial forearm free flap (RFFF) memiliki beberapa kelebihan dan kekurangan. Ini memiliki karakteristik unik dari jaringan tipis dan lentur. Flap ini mungkin diindikasikan ketika defek membutuhkan lipatan tipis dengan sedikit jaringan lunak atau beberapa skin island yang perlu disediakan. Tanda seperti gejala perfusi digit perifer yang buruk merupakan kontraindikasi pengambilan pedikel arteri radial. Persiapan untuk prosedur RFFF meliputi anamnesis, pemeriksaan fisik, dan pemeriksaan penunjang. Beberapa langkah persiapan intraoperatif juga harus dilakukan.

Kata Kunci: Radial Forearm Free Flap; Free flaps; Bedah mikro; Bedah mikro rekonstruksi
\end{abstract}

Conflicts of Interest Statement:

The author(s) listed in this manuscript declare the absence of any conflict of interest on the subject matter or materials discussed.

\section{SUPPORTING INFORMATION}

Additional supporting information may be found online on the JPRjournal Official YouTube channel: https://youtu.be/LAMDi7Q5G5M 


\section{INTRODUCTION}

Radial forearm flap is fasciocutaneous flap from the volar aspect of the forearm that based on the perforator of radial artery. It has become the work-horse free flap especially for tissue replacement on head and neck region, due to its unique characteristic of thin and pliable tissue. Radial forearm free flap (RFFF) may also become an osteocutaneous flap that include part of radial bone. 1,2

The RFFF has several advantages, such as great pliability and facilitates complex threedimensional molding, thin flap with minimal soft tissue bulk, easy and fastidious flap elevation, as well as large caliber, long and reliable pedicles. This free flap can also include nerve for sensate flap and provides non-hairy skin, that is perfect for head, neck and intraoral reconstruction. In RFFF, large flap may be harvested, up to $30 \times 15$ $\mathrm{cm}$ in size with multiple skin islands. This flap can also include palmaris longus tendon with the flap and able to incorporate segment of radius bone. Its distant location of donor site from head and neck resection making it is possible for simultaneous harvesting and resection (2-team approach). ${ }^{1}$

Nevertheless, the RFFF has several disadvantages as well. This flap mostly requires skin grafting for donor site closures and loss of sensation on the radial side of forearm may be present if cutaneous branches of radial nerve injured. This flap also sacrifices major vessels (radial artery) from upper extremities and result conspicuous donor site scar that can only be hidden with long sleeve clothes. Skin graft may fail if tendon is exposed during flap elevation and wrist joint stiffness due to prolonged immobilization post-operatively may occur. Radial bone is prone to pathologic stress fracture if parts of it were taken with flaps. Moreover, this flap is generally avoided in this era of perforator flap. It cannot obliterate defects due to its thin properties. While the veins involved might be damaged due to chemotherapy drugs, attention also should be directed to cephalic vein which commonly be damaged due to IV catheter placement. ${ }^{1}$

\section{INDICATIONS}

The indications of RFFF are related with its advantages. It may be indicated when a defect requires a thin flap with little bulk of soft tissue or multiple skin islands are needed. If a shorter duration of surgery is required, RFFF procedure can be also conducted since the harvesting process is simple and simultaneous harvesting and resection can be performed due to the distant location. 1,3

\section{CONTRAINDICATIONS}

Meanwhile, its contraindication follows the general contraindication of microvascular free tissue transfer. Physical signs and symptoms of poor peripheral digit perfusion or poor wound healing due to comorbid will contraindicate the harvest of the radial artery pedicle. Certain identifiable radial artery anomalies and prior surgical or traumatic injury to the radial artery also contraindicate the procedure. ${ }^{4}$

\section{PREPARATIONS}

Careful consideration must be taken to assess the eligibility of the condition of the patients. Patients should be examined using a grading from American Society Anesthesiologist (ASA) for preoperative preparation. The haemogloblin level, baseline hand functions including nerve function and vessel patency should be taken into account to avoid problems in the future. 1

Patient counseling is often missed and should be conducted properly. Unfavorable scar on the donor site is the most dreadful morbidity that patient should be aware off. The loss of sensation and stiffness of the hands are common, but avoidable. ${ }^{1}$

During history taking, identification of peripheral vascular disease, deep vein thrombosis, venous static disease, arteritis, previous surgery and trauma in donor area must be accounted. History of chemotherapy infusion on upper extremity vessels is very important. The chemotherapy solution may impair the vein patency especially in superficial vein system. Identification of dominant hand is paramount, as it is better to use the non-dominant hand as donor site. ${ }^{1}$

There are several physical examinations that should be done prior to the procedure, such as performing Allen's test to ensure the radial and ulnar artery patency, looking for sign of intravenous catheter or blood drawing pricks that may injure cephalic vein and performing basic hand function test, including sensoric and motor function. ${ }^{1}$

Supporting examinations that should be done before the surgery, such as CT angiography, could be done especially in patients with history of trauma in the donor area or peripheral vascular disease. Ultrasonography can be used to measure the quality of blood flow to radial artery and to 
detect thrombus, as well as finger palpation, or hand-held vascular doppler with $8 \mathrm{mHz}$ probe which is commonly used and is adequate to check the vessel quality. ${ }^{1}$

Several steps of intraoperative preparation should be done, such as placing the patient on supine position with the volar aspect facing up to the roof and decide the appropriate donor site. It is better to use non-dominant hand as the donor. It is also necessary to make sure the Allen's test result is positive. Do not insert IV line on the operated extremities. Meanwhile, deep venous catether or leg IV access can be used.

Pneumatic tourniquet should be prepared and placed proximally to the elbow. Place soft padding base to avoid skin erosion. Set the tourniquet pressure from $200-250 \mathrm{mmHg}$ for adult with 90 minutes timer. If pneumatic tourniquet is not available, a sterilized elastic or rubber band tourniquet can be prepared. Then drape the arm up to the elbow and mark the anatomic landmark for radial forearm free flap harvesting. Distal flap border is marked at the proximal wrist crease and the ulnar margin of flap is outlined over the flexor carpi ulnaris (FCU) muscle. Radial margin is outlined over the cephalic vein. If cephalic vein is not used, the radial margin is placed over the brachioradialis muscle. The proximal margin depends on the flap dimension needed, as the radial artery perforators supply almost the whole volar side of forearm. In general, the proximal margin is distal to the bifurcation of brachial artery to radial and ulnar artery. After that, the course of radial artery is marked from $1 \mathrm{~cm}$ distal to the center of cubital crease to scaphoid tuberosity. Flap size can reach up to $15 \mathrm{~cm}$ width and $30 \mathrm{~cm}$ length for adult or depends on the arm size. Later on, the lazy-S incision from the proximal margin of the flap to the cubital area may help for wider exposure and easier dissection. ${ }^{1}$

\section{SUMMARY}

Radial forearm flap is fasciocutaneous flap from the volar aspect of the forearm that based on the perforator of radial artery. Indications and contraindications should be determined before surgery through history taking, physical examinations and supporting examinations.

\section{Correspondence regarding this article should be addressed to:}

Parintosa Atmodiwirjo, MD.

Reconstructive Microsurgery Section, Division of Plastic

Surgery, Dr. Cipto Mangunkusumo National Hospital,

Universitas Indonesia. Jakarta 12310, Indonesia.

E-Mail: parintosa.atmodiwirjo@ui.ac.id

\section{REFERENCES}

1. Atmodiwirjo $\mathrm{P}$, Triatmoko SE. How To Harvest The Free Osteoseptocutaneous Fibular Flap: Step-by-Step. Jakarta: Lingkar Studi Bedah Plastik; 2019

2. Ramadan MR, Ralena NA, Triatmoko SE, Atmodiwirjo P. Early And Recent Development Of Reconstructive Microsurgery Subspeciality In Dr. Cipto Mangunkusumo National Hospital, Universitas Indonesia (1983-2020). Jurnal Plastik Rekonstruksi. 2020;6(2):281-90.

3. Atmodiwirjo P, Anggrahita T. Combined Free Flap Reconstruction Following Head And Neck Cancer Resection: Chimeric And Double Free Flap Reconstruction. Jurnal Plastik Rekonstruksi. 2019;5(1):188-194.

4. Shnayder Y, Tsue TT, Toby EB, Werle AH, Girod DA. Safe osteocutaneous radial forearm flap harvest with prophylactic internal fixation. Craniomaxillofac Trauma Reconstr. 2011;4(3):129-136. 